\title{
Feasibility Analysis Of Class Vi Students 'Books in Globalization Theme (Theme 4) Curriculum 2013 SDN 2 Padasuka
}

\author{
Muhammad Nurjamaludin, Nabila Aprilia, Dani Gunawan, Neni Nadhiroti \\ Muslihah
}

Institut Pendidikan Indonesia

mnur@institutpendidikan.ac.id

Article History

accepted 05/11/2020

approved 10/11/2020

published 01/02/2021

\begin{abstract}
textbooks are one of the teaching materials that can influence in learning activities, because they can be a reference for teachers and students. The purpose of this study was to determine the four standard feasibility of a grade VI student book on the theme of globalization in the curriculum 2013. The research method used in this study is qualitative with a type of descriptive approach that is library research. Participants or research objects that act as a source of data research information are the books of grade VI students and teachers. The data collection techniques used are documentation and interview techniques. Based on the results of the research analysis, it shows that the average value of the standardized analysis of the grade student book on the theme of globalization obtained a percentage $85,31 \%$ with the title "very worthy". Thus this book can be used as best as possible.
\end{abstract}

Keywords: analysis, feasibility, student book with the theme of globalization

\begin{abstract}
Abstrak
Buku teks merupakan salah satu bahan ajar yang dapat mempengaruhi dalam kegiatan pembelajaran, karena dapat menjadi acuan bagi guru maupun siswa. Tujuan penelitian ini adalah untuk mengetahui empat standar kelayakan buku siswa kelas VI tema globalisasi kurikulum 2013. Metode penelitian yang digunakan dalam penelitian ini adalah kualitatif dengan jenis pendekatan deskriptif bersifat studi pustaka (library research). Partisipan atau objek penelitian yang berperan sebagai sumber data/informasi penelitian ini adalah buku siswa kelas VI dan guru-guru kelas. Teknik pengumpulan data yang digunakan adalah teknik dokumentasi dan wawancara. Berdasarkan hasil analisis penelitian menunjukkan bahwa nilai rata-rata analisis standar kelayakan buku siswa kelas VI tema globalisasi memperoleh persentase $85,31 \%$ dengan predikat "Sangat Layak". Dengan demikian, buku siswa ini dapat digunakan dengan sebaik mungkin.
\end{abstract}

Kata kunci: analisis, kelayakan, buku siswa tema globalisasi

Social, Humanities, and Education Studies (SHEs): Conference Series https://jurnal.uns.ac.id/shes

p-ISSN 2620-9284

e-ISSN 2620-9292 


\section{PENDAHULUAN}

Pendidikan merupakan suatu kebutuhan yang harus ditempuh oleh setiap manusia. Mewadahi suatu pendidikan, pemerintah menyelenggaraannya ke dalam bentuk kurikulum untuk menjadi pengaturan dan perencanaan dalam pembelajaran. Adapun menurut Nasution (2006, hlm. 5) menyatakan bahwa kurikulum adalah sebagai suatu rencana yang disusun untuk melancarkan proses belajar mengajar di bawah bimbingan dan tanggung jawab sekolah atau lembaga pendidikan beserta staf pengajarnya. Disesuaikannya pendidikan dengan era perkembangan, maka pada saat ini negara memberlakukannya kurikulum 2013 sebagai pengembangan dari kurikulum sebelumnya. Pada kurikulum 2013 yang semula pembelajarannya menganut setiap mata pelajaran, kini diintegrasikan menjadi pembelajaran tematik. Pembelajaran tematik adalah pembelajaran terpadu yang menggunakan tema untuk mengatikan beberapa mata pelajaran sehingga dapat memberikan pengalaman yang bermakna kepada siswa (Majid, 2014, hlm.80).

Pembelajaran tematik memerlukan adanya sumber acuan yang dapat digunakan dalam proses kegiatan belajar mengajar. Salah satu sumber acuan yang telah difasilitasi oleh pemerintah yaitu buku teks bagi guru (buku guru) dan siswa (buku siswa). Buku guru adalah buku panduan bagi guru dalam melaksanakan pembelajaran di kelas yang berisi langkah-langkah pembelajaran yang didesain menggunakan pendekatan saintifik sesuai dengan kurikulum 2013 (Sari, 2017, hlm. 5). Sedangkan buku siswa menurut Uswatun dalam Izzatunnisa (2016, hlm. 8) yaitu suatu buku yang berisi materi pelajaran berupa konsep-konsep atau pengertian-pengertian yang akan dikonstruksi siswa melalui masalah-masalah yang ada di dalamnya yang disusun berdasarkan pendekatan.

Sebagai pedoman pembelajaran di kurikulum 2013, buku guru dan buku siswa haruslah memiliki kriteria yang baik dan benar. Apabila terdapat ketidaksesuaian dengan apa yang akan dicapai pada buku, maka sebelum diimplementasikan kepada siswa buku yang bersangkutan harus dianalisis terlebih dahulu. Kewajiban menganalisis tersebut sudah seharusnya dilakukan oleh para guru. Akan tetapi, masih terdapat beberapa guru yang mengacuhkan dan kurang memperhatikan kriteria kelayakan pada buku teks. Hal ini didukung berdasarkan pengamatan observasi dan wawancara kepada guru kelas VI SDN 2 Padasuka, beliau menyadari bahwa masih belum sepenuhnya melakukan penganalisisan terhadap buku guru dan buku siswa dengan alasan terlalu banyak dilakukan, sehingga telah terjadi kesimpangan pada buku guru dan buku siswa di tema sebelumnya. Akibatnya apabila buku guru dan buku siswa tidak diperhatikan siswa bisa saja menjadi tidak terlaksana dalam kompetensikompetensinya.

Adapun rumusan masalah penelitian ini adalah sebagai berikut: 1) Bagaimana standar kelayakan isi / materi dan penyajian pada Buku Siswa kelas VI SD/MI tema globalisasi (tema 4) kurikulum 2013 di SDN 2 Padasuka? 2) Bagaimana standar kelayakan kebahasaan dan kegrafikan pada Buku Siswa kelas VI SD/MI tema globalisasi (tema 4) kurikulum 2013 di SDN 2 Padasuka?

Tujuan peneitian ini berdasarkan rumusan masalah yang ada, yakni dapat diuraikan sebagai berikut: 1) Untuk mengetahui bagaimana standar kelayakan isi / materi dan penyajian pada Buku Siswa kelas VI SD/MI tema globalisasi (tema 4) kurikulum 2013 di SDN 2 Padasuka. 2) Untuk mengetahui bagaimana standar kelayakkan kebahasaan dan kegrafikan Buku Siswa kelas VI SD/MI tema globalisasi (tema 4) kurikulum 2013 di SDN 2 Padasuka. Istilah kurikulum dalam dunia pendidikan sudah tidak asing lagi didengar. Kurikulum 2013 merupakan kurikulum yang diberlakukan pada saat ini di negara Indonesia. Kurikulum 2013 berbasis kompetensi dapat dimaknai sebagai sesuatu konsep kurikulum yang menekankan pada pengembangan kemampuan melakukan (kompetensi) tugas-tugas dengan standar 
performansi tertentu, sehingga hasilnya dapat dirasakan oleh peserta didik, berupa penguasaan terhadap seperangkat kompetensi tertentu (Sulaeman, $2015 \mathrm{hlm}$. 81).

Penerapan dari kurikulum 2013 dalam kegiatan belajar mengajar dengan diimplementasikannya pembelajaran tematik. Menurut Depdiknas (2003) dalam Majid (2014, hlm. 4) mengemukakan bahwa pembelajaran tematik adalah suatu strategi pembelajaran yang melibatkan beberapa mata pelajaran untuk memberikan pengalaman yang bermakna kepada peserta didik. Pembelajaran tematik merupakan pembelajaran yang diintegrasikan dari beberapa mata pelajaran.

Sumber belajar pada pembelajaran tematik yaitu menggunakan buku teks bagi guru (buku guru) dan bagi siswa (buku siswa). Pada penelitian ini mengambil salah satu sumber acuan untuk melakukan analisis pada buku siswa. Buku ini digunakan siswa sebagai panduan aktivitasnya dalam menguasai kompetensi tertentu. Maka dari itu, buku siswa haruslah memenuhi kriteria yang baik dan benar agar mampu menarik minat peserta didik untuk mempelajarinya sesuai kaidah-kaidah keilmuan. Menurut Hayati (2011, hlm. 54) berpendapat bahwa setiap buku teks harus memenuhi standarstandar tertentu yang ditetapkan sesuai dengan kebutuhan, tuntutan kurikulum dan perkembangan ilmu pengetahuan dan teknologi. Standar yang menjadi arahan tersebut mencakup empat aspek kelayakan buku teks, yaitu aspek isi/materi, penyajian, bahasa, dan kegrafikan

\section{METODE}

Metode yang digunakan dalam penelitian ini adalah deskriptif kualitatif, karena data-data yang akan diteliti merupakan data verbal berupa kata-kata, atau gambar. Jenis penelitian ini adalah bersifat studi pustaka (library research)., yaitu pertama mencatat semua temuan yang didapatkan dalam setiap sumber, kedua memadukan segala temuan baik teori atau temuan langsung dari informan, ketiga menganalisis segala temuan dari berbagai sumber yang berkaitan dengan wacana yang akan dibahas didalam buku siswa, dan keempat memberikan gagasan dalam hasil penelitian dan mengkolaborasikan pemikiran-pemikiran yang berbeda ataupun sama. Partisipan atau objek penelitian yang paling berperan untuk menjadi sumber data dan informasi bagi penelitian ini adalah buku siswa kelas VI SD/MI tema globalisasi. Teknik pengumpulan data yang digunakan adalah teknik dokumentasi dan wawancara, dimana peneliti melakukan identifikasi dari buku-buku, jurnal, ataupun informasi lainnya untuk mencari hal-hal yang berhubungan dengan penelitian.

Instrument yang digunakan dalam dokumentasi yakni format lembar penelitian yang telah disesuaikan dengan kriteria yang ditentukan dari BSNP dan Pusat Perbukuan. sedangkan instrument yang digunakan dalam wawancara, yakni pedoman wawancara yang berisi sejumlah daftar pertanyaan yang akan diajukan.

Analisis data dilakukan dengan mengguanakan model Miles dan Huberman. Menurut Miles dan Huberman (1984) dalam Sugiyono (2017, hlm. 246) mengemukakan bahwa aktivitas dalam analisis data kualitatif dilakukan secara interaktif dan berlangsung secara terus menerus sampai tuntas, sehingga datanya sudah jenuh. Berikut langkahlangkah analisis data menurut Sugiyono (2017, hlm. 246) yaitu:

1. Reduksi data: data yang diperoleh dari lapangan cukup banyak, maka perlu dicatat secara teliti dan rinci. Mereduksi data berarti merangkum, memilih halhal pokok, dan memfokuskan hal-hal yang penting.

2. Penyajian data: langkah selanjutnya penyajian data untuk memahami dengan mudah tentang apa yang terjadi

3. Verifikasi data: langkah ketiga menurut Miles dan Huberman adalah penarikan kesimpulan. 
HASIL DAN PEMBAHASAN

Hasil analisis kelayakan buku siswa kelas VI tema globalisasi mencakup empat standar kelayakan, yaitu:

1. Standar Kelayakan Isi/Materi Buku Siswa Kelas VI Tema Globalisasi

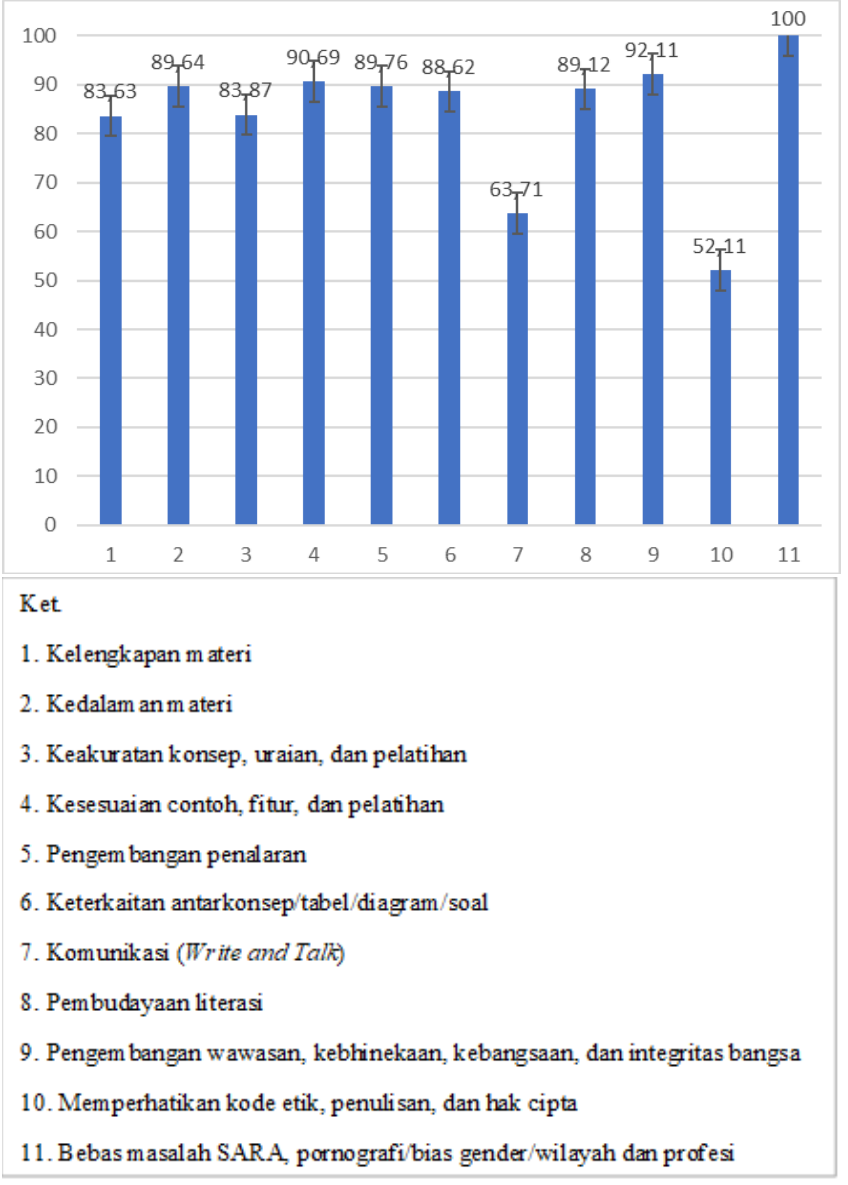

\section{Gambar 1. Grafik Analisis Kelayakan Isi/Materi}

Berdasarkan gambar grafik kelayakan isi/materi di atas memiliki hasil persentase dari beberapa butir komponen yaitu 1) pada kelengkapan isi memiliki persentase 83,63 dengan predikat "Baik", 2) kedalaman materi memiliki persentase 89,64 dengan predikat "Sangat baik", 3) subkomponen keakuratan konsep uraian dan pelatihan memiliki persentase 83,87 dengan predikat "Baik", 4) pada kesesuaian contoh fitur dan pelatihan memiliki persentase 90,69 dengan predikat "Sangat baik", 5) subkomponen pengembangan penalaran memiliki predikat 89,76 dengan predikat "Sangat baik", 6) pada keterkaitan antar konsep/tabel/diagram/soal memiliki persentase 88,62 dengan predikat "Sangat baik", 7) subkomponen komunikasi memiliki persentase 63,71 dengan predikat "Cukup baik", 8) butir komponen pembudayaan literasi memiliki persentase 89,12 dengan predikat "Sangat baik", 9) pada pengembangan wawasan kebhinekaan kebangsaan dan integritas bangsa memiliki persentase 92,11 dengan predikat "Sangat baik", 10) pada butir kode etik penulisan dan hak cipta memiliki persentase 52,11 dengan predikat "Kurang baik", dan 11) bebas SARA, pronografi/bias gender/wilayah dan profesi memiliki persentase 100 dengan predikat "Sangat baik".

Dari perolehan hasil butir-butir komponen standar kelayakan isi/materi dalam buku siswa kelas VI tema globalisasi memiliki nilai rata-rata $83,93 \%$ dengan predikat "Layak".

2. Standar kelayakan penyajian buku siswa kelas VI tema globalisasi 
SHEs: Conference Series 4 (1) (2021) $123-130$

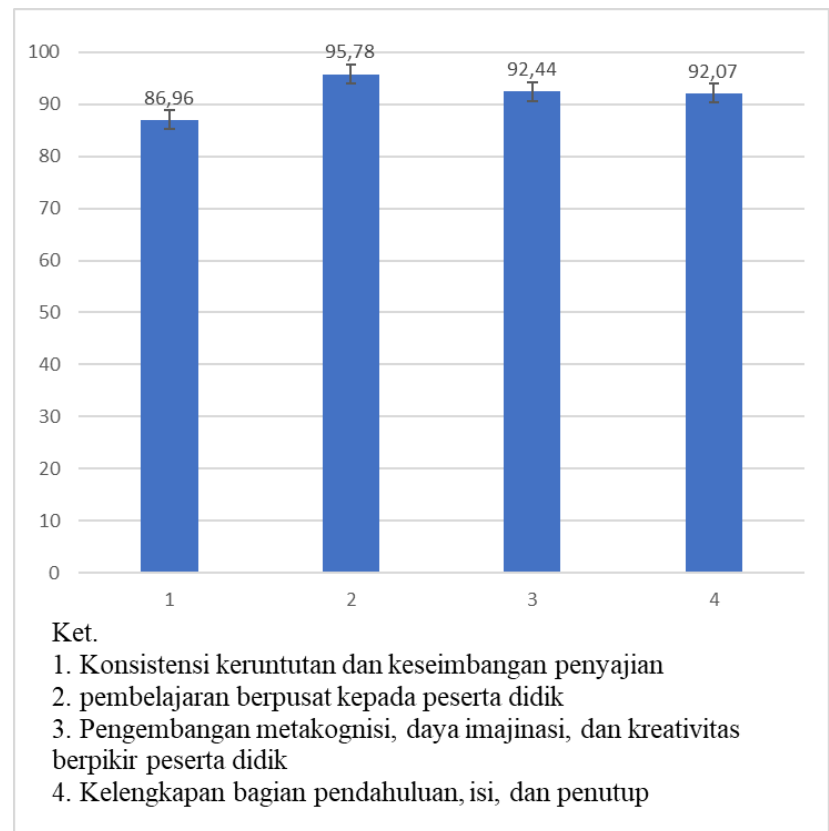

\section{Gambar 2. Grafik Analisis Kelayakan Penyajian}

Berdasarkan gambar grafik di atas memiliki hasil persentase dari beberapa butir komponen yaitu 1) konsistensi keruntutan dan keseimbangan penyajian memiliki persentase 86,96 dengan predikat "sangat baik", 2) pada butir komponen pembelajaran berpusat pada siswa memiliki persentase 96,78 dengan predikat "sangat baik", 3) pada pengembangan metakognisi, daya imajinasi dan kreativitas memiliki persentase 92,44 dengan predikat "sangat bai", dan 4) pada butir kelengkapan bagian pendahuluan, isi dan penutup memiliki persentase 92,07 dengan predikat "sangat baik".

Dari hasil persentase di atas dapat ditemukan rata-rata dari standar kelayakan penyajian buku siswa kelas VI tema globalisasi memiliki persentase $91,81 \%$ dengan predikat "sangat layak"

3. Standar kelayakan kebahasaan buku siswa kelas VI tema globalisasi

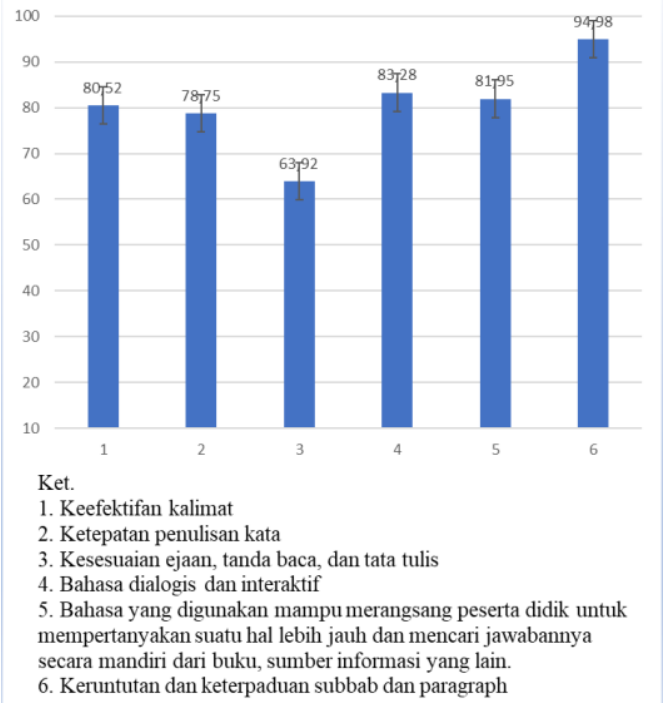

Gambar 3. Grafik Analisis Kelayakan Kebahasaan 
Berdasarkan gambar grafik di atas, memiliki hasil persentase dari beberapa butir komponen yaitu 1) keefektifan kalimat memiliki persentase 80,52 dengan predikat "Baik", 2) pada butir komponen ketepatan penulisan kata memiliki persentase 78,75 dengan predikat "Baik", 3) pada kesesuaian ejaan tanda baca dan tata tulis memiliki persentase 63,92 dengan predikat "Cukup baik", 4) pada bahasa dialogis dan interaktif memiliki persentase 83,82 dengan predikat "Baik", 5) butir komponen kelima bahasa yang digunakan memiliki persentase 81,95 dengan predikat "Baik", dan 6) pada butir komponen keruntutan dan keterpaduan subbab paragraph memiliki persentase 94,98 dengan predikat "Sangat baik".

Dari hasil persentase di atas, dapat ditentukan bahwa rata-rata dari standar kelayakan kebahasaan dari buku siswa kelas VI tema globalisasi adalah 80,56\% dengan persentase "Baik".

4. Standar kelayakan kegrafikan buku siswa kelas VI tema globalisasi

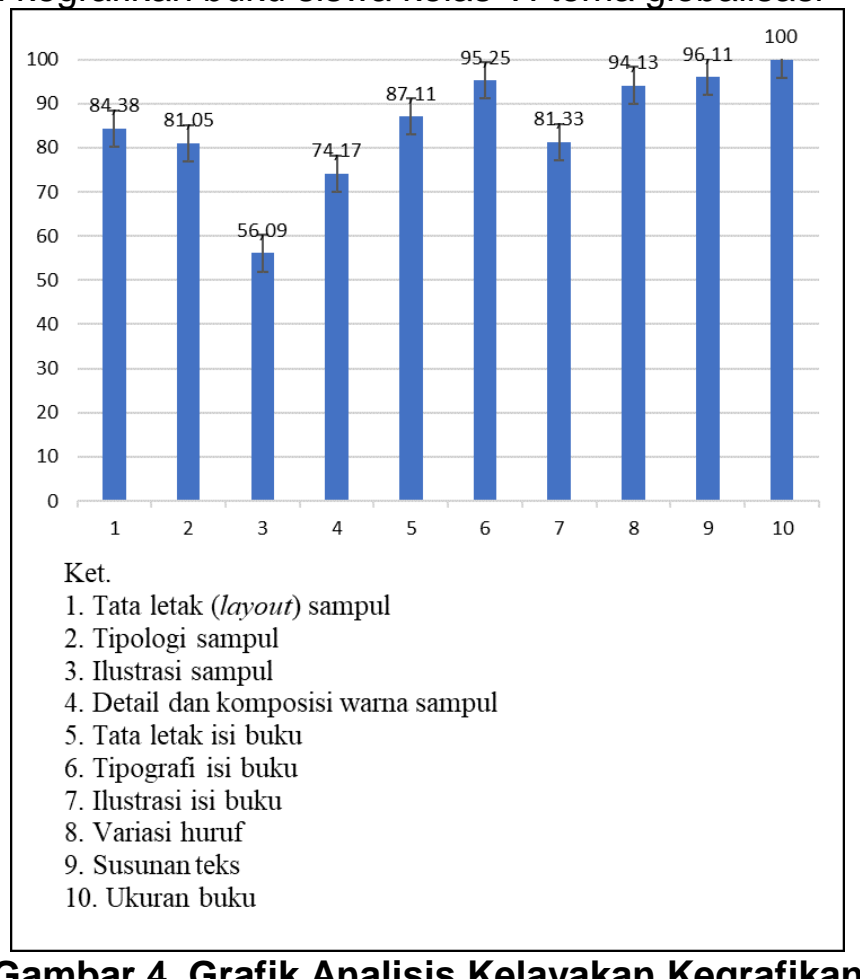

\section{Gambar 4. Grafik Analisis Kelayakan Kegrafikan}

Berdasarkan gambar grafik di atas dapat ditemukan hasil persentase dari setiap butir komponen standar kelayakan kegrafikan yaitu: 1) pada tata letak (layout) sampul memiliki persentase 84,38 dengan predikat "Baik", 2) butir komponen tipologi sampul memiliki persentase 81,05 dengan predikat "Baik", 3) lalu pada butir komponen ilustrasi sampul memiliki persentase 56,09 dengan predikat "Cukup baik", 4) butir komponen detail dan komposisi warna sampul memiliki persentase 74,17 dengan predikat "Baik", 5) kemudian tata letak isi buku memiliki persentase 87,11 dengan predikat "Sangat baik", 6) butir komponen tipografi isi buku memiliki persentase 95,25 dengan predikat "Sangat baik", 7) pada ilustrasi isi buku memiliki persentase 81,33 dengan predikat "Baik", 8) butir variasi huruf buku memiliki persentase 94,13 dengan predikat "Sangat baik", 9) butir komponen susunan teks memiliki persentase 96,11 dengan predikat "Sangat baik", dan 10) pada ukuran buku memiliki persentase $100 \%$ dengan predikat "Sangat baik".

Dari hasil persentase setiap butir komponen, dapat dihitung rata-rata dari standar kelayakan kegrafikan buku siswa kelas VI tema globalisasi adalah 84,96\% dengan predikat "Layak". 
Hasil perhitungan rata-rata secara keseluruhan dapat digambarkan sebagai berikut:

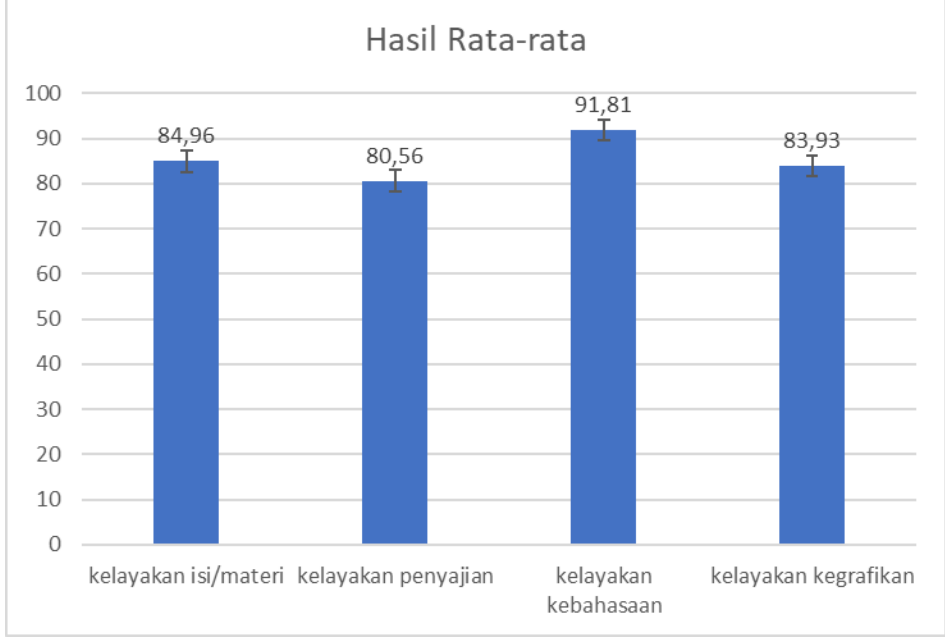

Gambar 5. Grafik Hasil Rata-rata Analisis Buku

Adapun akumulasi dari nilai rata-rata setiap standar kelayakan memiliki nilai perhitungan $85,31 \%$ dengan predikat "Sangat Layak". Sebagian besar menujukkan bahwa buku siswa kelas VI tema globalisasi sudah sesuai dengan standar-standar kelayakan yang telah ditetapkan oleh BSNP dan Pusat Perbukuan. Akan tetapi pada indikator yang belum mencapai nilai kriteria masih harus diperhatikan dan dapat dilakukan revisi kembali.

Analisis kelayakan buku teks memperlihatkan pentingnya standar kelayakan isi/materi, kelayakan penyajian, kelayakan kebahasaan, dan kelayakan kegrafikan yang terdapat dalam buku. Pembahasan dari hasil penilaian buku siswa kelas VI tema globalisasi menunjukkan bahwa buku tersebut memiliki komponen standar kelayakan yang berkategori sangat layak. Buku ini telah dianalisis oleh peneliti yang hasilnya tidak memiliki perbedaan secara signifikan dengan pengamat yang lainnya dari beberapa orang guru.

\section{SIMPULAN}

Berdasarkan hasil analisis penelitian yang dilakukan terhadap buku siswa kelas VI tema globalisasi dapat ditarik kesimpulan sebagai berikut:

1. Dari segi standar kelayakan isi/materi pada buku siswa kelas VI tema globalisasi memiliki predikat layak. Hal ini dikarenakan isi/materi yang terkandung dalam buku secara keseluruhan sudah sesuai berdasarkan butir komponen dan indikator yang ada dalam panduan instrument BSNP dan Pusat Perbukuan. Namun demikan, masih ada beberapa hal yang perlu diperbaiki/revisi. Sedangkan dari segi standar kelayakan penyajian, dapat dikategorikan sangat layak. Hal ini dikarenakan penyajian dalam buku siswa kelas VI tema globalisasi sudah sesuai menurut aturan dalam butir komponen dan indikator.

2. Dari segi standar kelayakan kebahasaan dalam buku siswa kelas VI tema globalisasi dapat dikategorikan baik. Hal ini dikarenakan penggunaan bahasa dalam buku sudah sesuai dengan pengembangan siswa, hanya saja masih ada beberapa yang perlu diperbaiki/revisi salah salah satunya yaitu penggunaan tanda baca yang masih perlu diperbaiki/direvisi. Sedangkan dari segi kergrafikan yaitu memiliki kategori layak. Hal ini dikarenakan Sebagian besar kegrafikan dalam buku siswa kelas VI tema globalisasi. Hanya ada beberapa saja yang perlu diperbaiki/direvisi. 


\section{DAFTAR PUSTAKA}

Hayati, L. (2011). Analisis Materi Graph Pada Buku Teks Pengantar Teori Dan Algoritma Graph. 54.

Izzatunnisa. (2016). Perbandingan Hasil Belajar Menggunakan Buku Siswa Bermuatan Nilai Ketuhanan dan Kecintaan Lingkungan Dengan Buku Siswa Konvensional Melalui Model PBL. Jurnal Pendidikan, 8.

Majid, A. (2014). Pembelajaran Tematik Terpadu. Bandung: PT. Remaja Rosdakarya. Nasution. (2006). Kurikulum dan Pengajaran. Jakarta: PT. Bumi Aksara.

Sari, F. R. (2017). Analisis Kesesuaian Buku Guru dan Buku Siswa Kelas IV SD/MI Tema Selalu Berhemat Energi. 40.

Sulaeman. (2016). Implementasi Kurikulum 2013 dalam Pembentukan Karakter Peduli Lingkungan Siswa SMA Negeri 6 Kendari. 13. 